\title{
Importance of wild foods to household food security in tropical forest areas
}

\author{
Jeferson Asprilla-Perea and José M. Díaz-Puente
}

\begin{abstract}
This article conducts a systematic literature review to analyze and consolidate empirical and/or theoretical evidence that shows the importance of wild foods for household food security in tropical forest areas. For these territories, forest plants, fungi and animals are not only important as a source of food, but also for generating community income. The main challenges related to wild foods are the negative effects on protection of species and the risks to human health when this food is consumed without testing for safety and nutrition. Once these challenges are met, wild foods can serve to bolster food security which can help to sustain territories in tropical forests.
\end{abstract}

Keywords Wild food $\cdot$ Household food security $\cdot$ Tropical forest areas

\section{Introduction}

Food and nutrition security have four dimensions: availability, accessibility, utilization and stability. At the local and national level, food availability is highly dependent on a sufficient amount of adequate food being obtained through production, import, storage and food aid (FAO 2011a). Accessibility refers to people having adequate resources to acquire food and a nutritious diet, considering, of course, that adequate supplies of food at the national and international levels do not necessarily lead to household food security (FAO 2011b). Utilization is the biological assimilation of food through a proper diet, drinking water, health and medical care, which meets all physical needs (FAO 2011b). Stability of food refers to maintaining availability, accessibility and utilization throughout time (FAO 2011b; Flores 2016).
At present, it is estimated that there are 795 million people in the world incapable of satisfying the necessary nutritional requirements to enjoy an active and healthy life. This is to say that approximately one in every nine people on the planet is undernourished. The majority of these people live in developing countries (FAO, FIDA and PMA 2015). The tropical forests in Latin America, the Caribbean, Africa and Asia are characterized by their complexity - the diversity of their species, short days, constant photoperiodicity, homogenous temperature, and the absence of thermal and hydrological stations (Whitmore 1983; Poorter and Bongers 1993; Lamprecht 1990). Approximately 800 million people live in these zones (Groom and Palmer 2012; Kashwan and Holahan 2014) of which $38 \%$ are undernourished (FAO, FIDA and PMA 2015). Fortunately, due to ancestral and traditional knowledge of the rural areas, which includes knowledge of the indigenous biodiversity of organisms that can be used as food, the percentage of undernourished is not likely to rise (Bennett 2002; Cole et al. 2014).

Wild foods include a set of edible products from different plant species, fungi and animals that have not yet been domesticated. Within this particular sgroup are cereals, tubers, vegetables, fruits, meats, eggs and others (Misra et al. 2013; Schulp et al. 2014; Termote et al. 2014; Erskine et al. 2015; Fa et al. 2015). Wild foods can constitute a source of nutrients that, when included in planning interventions to support food security (politics, plans, programs, and projects) could contribute to a reduction in the number of undernourished people 
in tropical forest territories of developing countries. However, in order to have better possibilities of successfully including wild foods for inhabitants of those territories, it is necessary to increase the understanding of their importance and contribution to household food security.

This study, through a systematic literature review, seeks to recognize and consolidate theoretical and/or empirical evidence that demonstrates the importance of wild foods for household food security in tropical forest areas, in order to answer the following questions: (1) What is the importance of forest plants, fungi and animals for household food security in tropical forest areas? (2) What are the main challenges to including wild foods in interventions supporting household food security in tropical forest areas?

\section{Methods}

A methodological process was implemented in this study which included three steps; 1) identification and gathering of documents; 2) development of the criteria for including documents; 3) data analysis and structuring of research findings (Labin 2008; Mavengahama et al. 2013).

\subsection{Identification and gathering of documents}

Scientific websites were consulted including: Web of Science $^{\mathrm{TM}}$ Core Collection, BIOSIS Citation Index ${ }^{\mathrm{SM}}$, BIOSIS Previews ${ }^{\circledR}$, Current Contents Connect ${ }^{\circledR}$, Derwent Innovations Index ${ }^{S M}$, Inspec $\circledast$, MEDLINE $®$, y SciELO Citation Index (all of them linked to WEB OF SCIENCE), as well as some searches in Google Academic. Searches were done looking for key words in the document titles using terms such as; "wild foods", "wild vegetables", "indigenous vegetables", "wild edible plants", "wild meat", "edible wild fruit", "Bush meat". Each of the words was also searched in combination with the expression "food security". Limitations in terms of language, years of publication and knowledge area were not scheduled.

\subsection{Criteria for Including Documents}

The only documents that were included were papers published in journals reviewed by scholarly peer evaluators or books published by recognized authors and reviewed by recognized editors; studies with theoretical and/or empirical results which made it possible to answer at least to one of the questions defined for the research; and studies carried out in tropical forest zones.

\subsection{Data analysis and structuring of research results}

The documents were analyzed in detail to answer the two questions defined above. When it was necessary and expedient, contributions were made to the results based on the empirical experiences of the authors of this paper and/or knowledge gained during technical discussions in frequent meetings.

The results of the data analysis were presented according to geographical areas; Africa, Asia and Latin America and the Caribbean. These areas correspond with those used by FAO, FIDA and PMA (2015) in their report on world food insecurity. Figure 1 shows the countries included in the data analysis of the study.

\section{Results}

\subsection{Importance of wild foods for household food security}

The use of species of wild plants, fungi and animals in tropical forest zones, has grown from ancestral practices that favor household food security in these territories, especially in rural areas. Although the information about this issue is scattered, some studies from different knowledge areas (ethnobotany, ethnozoology, economic botany, agronomy, economy etc.), have shown scientific use of wild foods, not only as a source of nutrition, but also for generating economic income in various communities.

\subsubsection{Use of wild plants and animals as food}

Although there are ongoing studies and research on wild food at the community level in tropical forests, it is still difficult to confirm the direct contribution of wild foods to food security. However, many academics think that the contribution of wild food is significant (World Health Organization (WHO) 1992; Ntiamoa-Baidu 1995; Fa et al. 2003; Nasi et al. 2011; Fa et al. 2015). For example, many authors (Olatunbosum et al. 1972; Ajayi 1978; Prescott-Allen and Prescott-Allen 1982; Asibey 1987; Hladik 1987) cited by Fa et al. (2003) argue that in some African regions $90 \%$ of the animal protein consumed comes from wild animals.

As for tropical forests in Africa, it is estimated that in central Africa, Democratic Republic of Congo, Republic of Congo, Central African Republic, Cameroon, Gabon and Equatorial Guinea, wild meat, especially in rural areas, represents a vital element of the human diet. This is due to the close cultural ties between wild resources and the communities, and to the lack of dietary alternatives and financial limitations (Wilkie and Carpenter 1999; Fa et al. 2003; Ling and Milner-Gulland 2006; Fa et al. 2015). An example of this is 


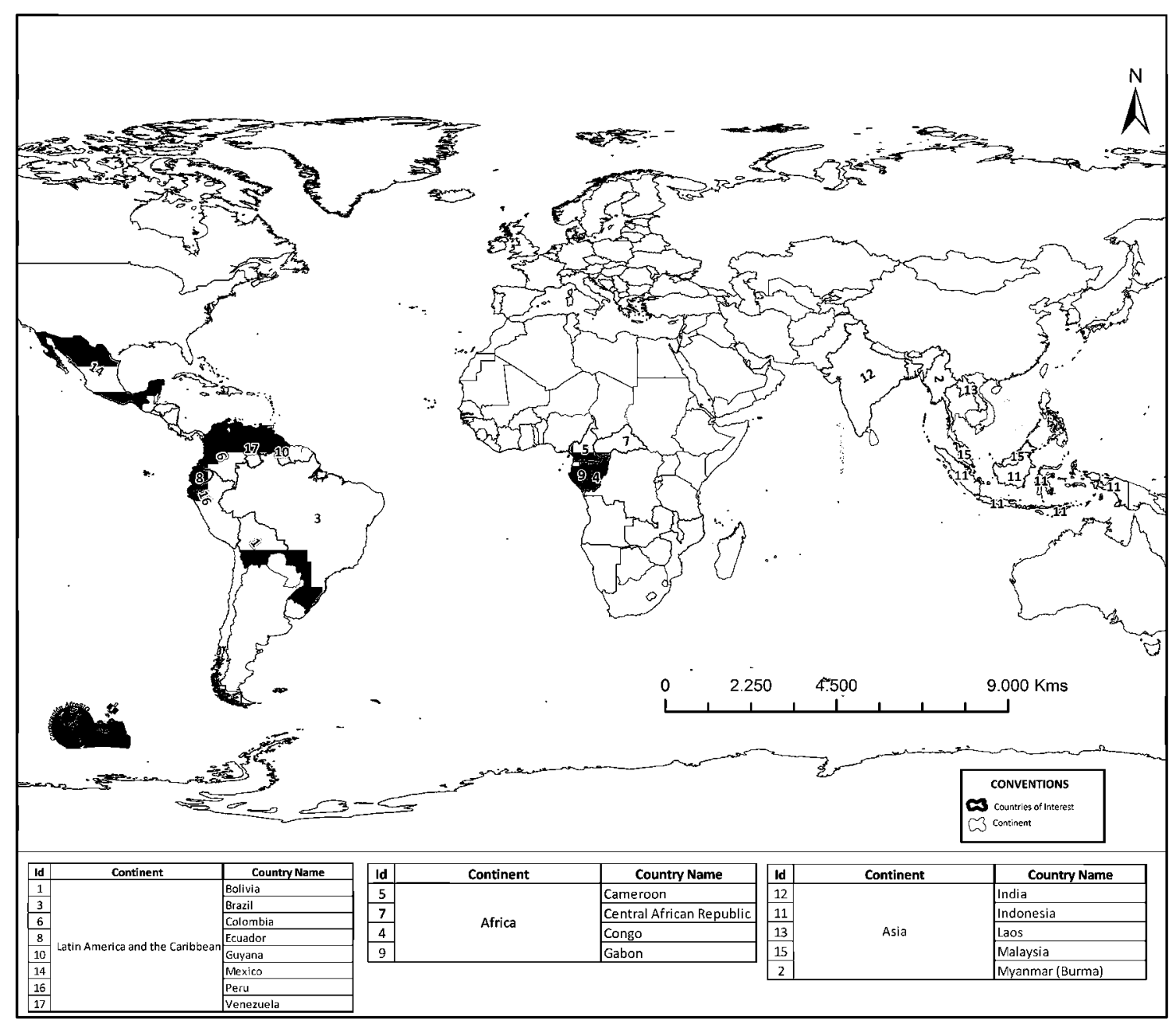

Fig. 1 Countries included in the data analysis

in the Congo basin where it is estimated that approximately five million tons of wild animal meat are consumed each year, leading it to be considered an important source of many nutrients - especially proteins, vitamin B, iron and zinc (Nasi et al. 2011).

Wild plants, fruits and vegetables have been used for a long time as part of the traditional diet in diverse locations (Keatinge 2012). In Sub-Saharan Africa, in spite of official statistics indicating low-level consumption of vegetables, wild vegetables are frequently consumed in rural communities within the tropical forest zones (Kamga et al. 2013). Termote et al. (2012) Wild edible plants also provide multiple benefits to rural families in the Democratic Republic of Congo because they are used as important component in the household diet. The excess is commercialized for sale in urban centers.

The northeastern hotspot region of India in Asia has high biodiversity and many multiethinic communities that are highly dependent on wild plants as a source of food (Saha et al. 2014). Likewise, a study carried out in the Similipal Bioserve Reserve (Odisha, India) reported that wild plants are an important source of food, especially when food availability through other sources is not present. The high biodiversity of wild plants as a source of food is significant due to the difficulty of cultivating land and limitations of access to the conventional food trade (Misra et al. 2013).

Other studies have documented the use of different forest plant species (fruits and vegetables) and animals as a fundamental part of rural diets in Indonesia and India. These products are also important to the economic activity of these populations (Kayang 2007; Binu 2010; Narayanan et al. 2011; Chandra et al. 2013; Luskin et al. 2014).

In many rural tropical forest areas in Latin America, such as in Colombia, Bolivia, Ecuador, Brazil, Peru and Mexico, wild species (plants and animals) are the main food source and contributor to household food security, especially in territories that are difficult to access from populated centers and/or the conventional food trade (Van den Eynden et al. 2003; Tejada et al. 2006; Asprilla-Perea and Hinestroza 2011; Pauro et al. 2011; Asprilla-Perea et al. 2012; Martínez-Pérez et al. 2012; Cruz et al. 2013; Álvarez 2014; Cruz et al. 2014; Grados and Peláez 2014; Bortolotto et al. 2015). 
In the Amazon, wildlife is the major source of animal protein for the population's daily diet (Robinson and Redford 1991; Townsend 1996; Bodmer et al. 1997; Robinson and Bennett 2000; Townsend and Rumiz 2003; Tejada et al. 2006). Animal protein is consumed not only due to cultural preferences, but because that meat is the most accessible and sustainable source of protein (Fa et al. 2003). According to Fa and Brown (2009) domestic livestock can be more expensive due to their low productivity in tropical areas.

\subsubsection{Generating incomes}

Commonly in tropical forest areas, wild foods generate family income by occasional sale of diverse species of forest plants, fungi and animals. The economic resources from these sales are generally used for household subsistence.

In African countries such as Equatorial Guinea, Gabon and the Democratic Republic of Congo, scientific evidence demonstrates that commercial hunting can generate increases in family income (Brown 2003; Brown and Williams 2003). It is supposed that greater household income contributes to household food security in these territories (Coad et al. 2010; Kümpel et al. 2010; Termote et al. 2012; Vega et al. 2013).

For rural communities that inhabit tropical forest territories in Latin America, especially in Colombia, wild foods play a fundamental role in generating economic income at the household level - particularly to satisfy their primary need for food, children's education and healthcare (Matallana and Lasso 2012). Activities include frequent hunting and the sale of meat and other sub-products derived from fauna (eggs), or from fruits, fungi and vegetables that are used in such homemade products as condiments, juices, marmalade, ice-cream and biscuits. The money gained from these sales is generally used to complement the household diet (for foods which are not produced by the family) or for the acquisition of school uniforms, utilities and other products necessary for the education of children and young people. Equally, the economic income obtained through the commercialization of wild foods is frequently used to pay for medical consultations and treatment at hospitals, public health centers or the ancestral medicine system that, for many communities in this region, is the only option.

\subsection{Wild foods as a resource for planning interventions to support food security: Main challenges}

In spite of the wide cultural ties between wild species and the human diet in tropical forest territories, it is likely that their consumption occurs due to diverse problems. The scientific community's main concerns relate to the negative effects indiscriminate use of the resources places on the conservation of biodiversity in the area, and the possible risks to human health because of the lack of assessment of nutritional and health benefits.

\subsubsection{Negative effects for the conservation of biodiversity}

As mentioned above, the inhabitants from tropical areas have long been obtaining food from the jungles. However, from an ecological point of view, several researchers are concerned that the excessive use of natural resources may lead to the extinction of certain species.

Several studies conducted in Africa, Latin America and the Caribbean also demonstrate concern over the excessive use of plants, fungi and wild animals that leads to a reduction in their populations, local extinction and the fragmentation of their habitat in the both the medium and long term. These can directly affect the functioning of ecosystems and people's livelihood. (Robinson and Bennett 2000; Peres 2001; Fa and Peres 2001; Bennett and Rao 2002; Fa et al. 2005; Laurance et al. 2006; Gardner et al. 2006; Wright and Muller-Landau 2006; Fa and Brown 2009). Similarly, Cullen et al. (2001) state that over-exploitation is the main reason for local extinction, which then negatively affects the balance of the ecosystem. According to Fa et al. (2003) there is strong empirical evidence that wildlife is threatened with extinction due to unplanned human interventions. It is widely agreed that such extinctions will cause serious consequences for future generations (Fa et al. 2003; Ziegler 2010).

\subsubsection{Possible risks for human health}

The use of plants, fungi and wild animals as dietary products is commonly not due to governmental food security policies but due to ancestral traditions of the community - which have their own sociocultural way of consuming and eating food. The scientific community has two main concerns. First, they are concerned about possible diseases being transmitted by handling and eating wild food. Thirty-five new infectious diseases among humans have been reported in the last decade (Karesh et al. 2005) and many of them supposedly result from collecting and consuming plants, fungi and wild animals (Feng et al. 1999; Leroy et al. 2004; Bell et al. 2004). Second, the lack of studies on their nutritional value, such as protein content, fats and minerals of the wild food means that an imbalance of nutrition is not identified or corrected and, as a result, people may not be consuming a good diet (Pandey et al. 2006; Keatinge 2012; Asprilla-Perea et al. 2012; Kamga et al. 2013).

\subsection{Research needs for the adequate inclusion of wild foods in food security planning}

The cultural and ancestral importance of plants, fungi and animals found in the diet of the inhabitants of tropical forests, 
leads to recognition of the potential of this resource for planning policies, plans, programs and projects to support food security, which may be pertinent and sustainable for these territories. However, it is necessary to carry out diverse scientific research studies that confront the challenges the topic presents. The principal research needs that have been identified are related to seven areas: (1) Increase the number of studies about the recognition and documentation of traditional use of wild species in the diets of communities who inhabit tropical forest territories. (2) Know the pattern of use of wild life in the diets of communities in tropical forest areas, with special emphasis on the relationships among species, culture and territory. (3) Identify the motivation for consuming this type of food, which will enable evaluation of whether the communities prefer to continue consuming wild foods in spite of other options. (4) Identify the nutritional value of the food which has been used by these communities. (5) Identify the value of the biological assimilation of these foods and their associated risks to human health. (6) Generate scientific knowledge about the best alternatives for sustainable exploitation in each case in each particular territory. (7) Assess the impact of the inclusion of wild foods in food security interventions.

\section{Conclusions}

In all tropical forest areas of Africa, Asia, Latin America and the Caribbean, forest plants, fungi and animals are a source of food that contributes to household food security using ancestral practices and biodiversity. In the rural communities of these areas, wild foods are used as the main alternative to animal proteins, cereals, tubers, vegetables and fruits, and in urban zones they are important in complementing conventional foods (contributing to availability). Also, wild foods contribute to household food security by generating income from activities such as hunting, gathering, harvesting and/or cultivating plants, fungi and animals. These activities are of vital importance for the subsistence of many communities (contributing to access).

The inclusion of wild foods in the planning of food security interventions would make these interventions more pertinent and sustainable owing to the opportunities for articulating policies, programs and projects with ancestral uses of wild food. These interventions could also be more sustainable because they would reduce dependency on conventional foods that in many cases are difficult to produce, have high costs, or are generally not consumed due to cultural resistance. These aspects have great relevance to the lack of sustainability of some publicly financed projects or cooperation projects when the project funding stops. Nevertheless, in order to increase the successful possibilities of the inclusion of wild foods in the interventions aimed at supporting food security, it is necessary to carry out diverse scientific and technical research studies to confront the still pending challenges in this matter.

Despite the evidence which demonstrates the contribution wild foods make to household food security in tropical forest areas, challenges exist, limiting their inclusion in policies, programs and projects to reduce the number of undernourished people in these areas. These challenges are related to the negative effects on the conservation of biodiversity due to unplanned extractive practices, and the possible risks to human health because of lack of nutritional and health assessments of the foods. The first challenge can be addressed through ensuring sustainable strategies which permit the estimation of the abundance and density of the wild food population subject to consumption. These include projection of sustainability; measuring the impact generated by the extraction on the natural population and exploring the possibilities for crop cultivation or animal breeding. The second challenge can be met by decision makers of these territories to implement systematic, multidisciplinary studies that document the nutritional potentials of the foods used ancestrally and their value as alternatives to conventional foods, as well as their safety for human consumption.

Acknowledgements This document is part of a $\mathrm{PhD}$ thesis with the Superior School of Agricultural Engineering, Food and Biosystems of the Technical University of Madrid, Spain. An earlier version of this paper was presented at the BHP Billiton Sustainable Communities and UCL Grand Challenge Symposium 9-10 November 2015 on "Global Food Security: Adaptation, Resilience and Risk". Support to travel and discussions at the symposium, especially from Raimund Bleischwitz and Julia Tomei, are gratefully acknowledged.

\section{Compliance with ethical standards}

Conflict of interest The authors declare that they have no conflict of interest.

\section{References}

Ajayi, S. S. (1978). Pattern of bushmeat production, preservation and marketing in West Africa. Nigerian Journal of Forestry, 8, 48-52.

Álvarez, L. (2014). Plantas promisorias de uso alimenticio del Darién, Caribe colombiano. Boletín de Antropología, 29(48), 41-65.

Asibey, E. O. (1987). Wildlife issues in sub-Saharan Africa. Based on the work of EO Asibey. In Expert Consultation on Forestry and Food Production/Security. Bangalore (India) (pp. 14-20) Feb 1988.

Asprilla-Perea, J., \& Hinestroza, L. (2011). Manejo Tradicional de Fauna silvestre en Comunidades Negras del Pacifico Norte Colombiano. Cali: Alfa Graphics.

Asprilla-Perea, J., Mosquera, Y., \& Moreno, A. (2012). Proechimys semispinosus (Ratón de Espinas): Una especie de fauna silvestre con Potencial Promisorio para comunidades negras del departamento del Chocó, Pacífico Colombiano. Caldasia, 34(2), $385-396$. 
Bell, D., Roberton, S., \& Hunter, P. R. (2004). Animal origins of SARS coronavirus: Possible links with the international trade in small carnivores. Philosophical Transactions of the Royal Society of London B: Biological Sciences, 359(1447), 1107-1114.

Bennett, E. L. (2002). Is there a link between wild meat and food security? Conservation Biology, 16(3), 590-592.

Bennett, E. L., \& Rao, M. (2002). Wild meat consumption in Asian tropical forest countries: Is this a glimpse of the future for Africa. In S. Mainka \& M. Trivedi (Eds.), Links between Biodiversity, Conservation, Livelihoods and Food Security: The Sustainable Use of Wild Species for Meat (pp. 39-44). Switzerland/Cambridge: IUCN Gland.

Binu, S. (2010). Wild edible plants used by the tribals in Pathanamthitta district, Kerala. Indian Journal of Traditional Knowledge, 9(2), 309-312.

Bodmer, R. E., Penn, J. W., Puertas, P. E., Moya, L. I., \& Fang, T. G. (1997). Linking conservation and local people through sustainable use of natural resources: Community-based management in the Peruvian Amazon. In Harvesting Wild Species (pp. 315-358). Baltimore: John Hopkins University Press.

Bortolotto, I. M., de Mello Amorozo, M. C., Neto, G. G., Oldeland, J., \& Damasceno-Junior, G. A. (2015). Knowledge and use of wild edible plants in rural communities along Paraguay River, Pantanal, Brazil. Journal of Ethnobiology and Ethnomedicine, 11(1), 46.

Brown, D. (2003). Bushmeat and poverty alleviation: Implications for development policy. ODI Wildlife Policy Briefing.

Brown, D., \& Williams, A. (2003). The case for Bushmeat as a component of development policy: Issues and challenges. International Forestry Review, 5, 148-155.

Chandra, K., Nautiyal, B. P., \& Nautiyal, M. C. (2013). Ethno-botanical resources as supplementary foods and less known wild edible fruits in district Rudraprayag, Uttarakhand, India. Journal of Human Ecology, 42(3), 259-271.

Coad, L., Abernethy, K., Balmford, A., Manica, A., Airey, L., \& MilnerGulland, E. J. (2010). Distribution and use of income from Bushmeat in a Rural Village, Central Gabon. Conservation Biology, 24(6), 1510-1518.

Cole, L. E., Bhagwat, S. A., \& Willis, K. J. (2014). Recovery and resilience of tropical forests after disturbance. Nature Communications, 5.

Cruz, M. P., Peroni, N., \& Albuquerque, U. P. (2013). Knowledge, use and management of native wild edible plants from a seasonal dry forest (NE, Brazil). Journal of Ethnobiology and Ethnomedicine, 9(1), 79 .

Cruz, M. P., Medeiros, P. M., Sarmiento-Combariza, I., Peroni, N., \& Albuquerque, U. P. (2014). "I eat the manofề so it is not forgotten": Local perceptions and consumption of native wild edible plants from seasonal dry forests in Brazil. Journal of Ethnobiology and Ethnomedicine, 10(1), 45.

Cullen, L. J., Bodmer, R. E., \& Valladares-Padua, C. (2001). Ecological consequences of hunting in Atlantic forest patches, Sao Paulo, Brazil. Oryx, 35, 137-144.

Erskine, W., Ximenes, A., \& Glazebrook, D. (2015). The role of wild foods in food security: The example of Timor-Leste. Food Security, $7(1), 55-65$.

Fa, J. E., \& Brown, D. (2009). Impacts of hunting on mammals in African tropical moist forests: A review and synthesis. Mammal Review, 39(4), 231-264.

Fa, J. E., \& Peres, C. A. (2001). Game vertebrate extraction in African and Neotropical forests: An intercontinental comparison. In Conservation of exploited species (pp. 203-241). Cambridge: Cambridge University Press.
Fa, J. E., Currie, D., \& Meeuwig, J. (2003). Bushmeat and food security in the Congo Basin: Linkages between wildlife and people's future Environmental Conservation, 30, 71-78.

Fa, J. E., Ryan, S. L., \& Bell, D. J. (2005). Hunting vulnerability, ecological characteristics and harvest rates of bushmeat species in Afrotropical forests. Biological Conservation, 121, 167-176.

Fa, J. E., Olivero, J., Real, R., Farfán, M. A., Márquez, A. L., Vargas, J. M., Ziegler, S., Wegmann, M., Brown, D., Margetts, B., \& Nasi, R. (2015). Disentangling the relative effects of bushmeat availability on human nutrition in Central Africa. Scientific Reports, 5.

FAO. (2011a). Seguridad Alimentaria y Nutricional. Conceptos Básicos. Programa Especial para la Seguridad Alimentaria (PESA). http:// www.pesacentroamerica.org/biblioteca/2011/conceptos2011.pdf

FAO. (2011b). Una introducción a los conceptos básicos de la seguridad alimentaria. La Seguridad Alimentaria. Información para la toma de decisiones. http://www.fao.org/docrep/014/a1936s/al936s00.pdf

FAO, FIDA, \& PMA. (2015). El estado de la inseguridad alimentaria en el mundo 2015. Cumplimiento de los objetivos internacionales para 2015 en relación con el hambre: balance de los desiguales progresos. Roma, FAO. El estado de la inseguridad alimentaria en el mundo, 8-14.

Feng, G., Krejci, E., Molgo, J., Cunningham, J. M., Massoulié, J., \& Sanes, J. R. (1999). Genetic analysis of collagen Q: Roles in acetylcholinesterase and butyrylcholinesterase assembly and in synaptic structure and function. The Journal of Cell Biology, 144(6), 1349 1360.

Flores, Y. A. (2016). Seguridad y soberanía alimentaria, ¿una alternativa frente al problema del hambre? Encrucijada, Revista Electrónica del Centro de Estudios en Administración Pública de la Facultad de Ciencias Politicas y Sociales. Universidad Nacional Autónoma de México, 23(1), 1-16.

Gardner, T. A., Barlow, J., Parry, L. W., \& Peres, C. A. (2006). Predicting the uncertain future of tropical forest species in a data vacuum. Biotropica, 39, 25-30.

Grados, M., \& Peláez, F. (2014). Especies vegetales utilizadas por pobladores de Berlín, Bagua Grande (Amazonas, Perú) 2011 2012. Rebiolest, 2(2), 36 .

Groom, B., \& Palmer, C. (2012). REDD+ and rural livelihoods. Biological Conservation, 154, 42-52.

Hladik, C. M. (1987). Se Nourrir en Foret Équatoriale: Anthropologie Alimentaire Différentielle des Populations des Régions Forestières Humides d'Afrique. Research Team Report 263 (p. 35). Paris: Centre Nationale de Recherches Scientifiques.

Kamga, R. T., Kouamé, C., Atangana, A. R., Chagomoka, T., \& Ndango, R. (2013). Nutritional evaluation of five African indigenous vegetables. Journal of Horticultural Research, 21(1), 99-106.

Karesh, W. B., Cook, R. A., Bennett, E. L., \& Newcomb, J. (2005). Wildlife trade and global disease emergence. Emerging Infectious Diseases, 11(7), 1000-1002.

Kashwan, P., \& Holahan, R. (2014). Nested governance for effective REDD+: Institutional and political arguments. International Journal of the Commons, 8(2), 554-575.

Kayang, H. (2007). Tribal knowledge on wild edible plants of Meghalaya Northeast India. Indian Journal of Traditional Knowledge, 6(1), $177-181$

Keatinge, D. (2012). Vegetables: Less visible, but vital for human healthwhy nutrient-dense indigenous vegetables must be on the plate for economic development, food security, and health. AVRDC News Brief.

Kümpel, N. F., Milner-Gulland, E. J., Cowlishaw, G., \& Rowcliffe, J. M. (2010). Incentives for hunting: The role of Bushmeat in the household economy in rural Equatorial Guinea. Human Ecology, 38, 251264. 
Labin, S. N. (2008). Research synthesis: Toward broad-based evidence. In N. Smith \& P. R. Brandon (Eds.), Fundamental issues in evaluation (pp. 89-110). New York: Guilford.

Lamprecht, H. (1990). Silvicultura en los trópicos. Deutsche Gesellschaft für Technische Zusammernarbeit (GTZ). Germany.

Laurance, W. F., Croes, B. M., Tchignoumba, L., Lahm, S. A., Alonso, A., Lee, M. E., Campbell, P., \& Ondzeano, C. (2006). Impacts of roads and hunting on central African rainforest mammals. Conservation Biology, 20, 1251-1261.

Leroy, E. M., Rouquet, P., Formenty, P., Souquière, S., Kilbourne, A., Froment, J. M., et al. (2004). Multiple Ebola virus transmission events and rapid decline of central African wildlife. Science, 303(5656), 387-390.

Ling, S., \& Milner-Gulland, E. J. (2006). Assessment of the sustainability of bushmeat hunting based on dynamic bioeconomic models. Conservation Biology, 20, 1294-1299.

Luskin, M. S., Christina, E. D., Kelley, L. C., \& Potts, M. D. (2014). Modern hunting practices and wild meat trade in the oil palm plantation-dominated landscapes of Sumatra, Indonesia. Human Ecology, 42(1), 35-45.

Martínez-Pérez, A., López, P. A., Gil-Muñoz, A., \& Cuevas-Sánchez, J. A. (2012). Plantas silvestres útiles y prioritarias identificadas en la Mixteca Poblana, México. Acta Botánica Mexicana, 98, 73-98.

Matallana, C., Lasso C. A., \& Baptiste M. P. (2012). Carne de monte y consumo de fauna silvestre en la Orinoquia y Amazonia (Colombia y Venezuela). Memorias del Taller Regional Inírida, Guainía (Colombia) 2012. Instituto de Investigaciones de Recursos Biológicos Alexander von Humboldt, Universidad Nacional de Colombia, Sede Orinoquia, Instituto de Estudios de la Orinoquia y Corporación para el Desarrollo Sostenible del Norte y el Oriente Amazónico. $72 \mathrm{pp}$

Mavengahama, S., McLachlan, M., \& De Clercq, W. (2013). The role of wild vegetable species in household food security in maize based subsistence cropping systems. Food Security, 5, 227-233.

Misra, R. C., Sahoo, H. K., Pani, D. R., \& Bhandari, D. C. (2013). Genetic resources of wild tuberous food plants traditionally used in Similipal biosphere reserve, Odisha, India. Genetic Resources and Crop Evolution, 60(7), 2033-2054.

Narayanan, M. K. R., Anilkumar, N., Balakrishnan, V., Sivadasan, M., Alfarhan, H. A., \& Alatar, A. (2011). Wild edible plants used by the Kattunaikka, Paniya and Kuruma tribes of Wayanad District, Kerala, India. Journal of Medicinal Plants Research, 5(15), 3520-3529.

Nasi, R., Taber, A., \& Van Vliet, N. (2011). Empty forests, empty stomachs? Bushmeat and livelihoods in the Congo and Amazon basins. International Forestry Review, 13(3), 355-368.

Ntiamoa-Baidu, Y. (1995). Wildlife and food security in Africa. In FAO conservation guide 33 (p. 200). Rome: Food and Agriculture Organization of the United Nations.

Olatunbosum, D., Olayide, S. O., Idusogie, E. G., \& Abiagom, J. D. (1972). Role of fish and animal products in Nigerian agricultural development and nutrition. Ecology of Food and Nutrition, 1, 235-243.

Pandey, M., Abidi, A. B., Singh, S., \& Singh, R. P. (2006). Nutritional evaluation of leafy vegetable paratha. Joumal of Human Ecology, $19,155-156$.

Pauro, R., Juan, J., Gonzáles, M., Gamarra, C., Brenda, M., Pauro, R., et al. (2011). Plantas alimenticias, medicinales y biocidas de las comunidades de Muñani y Suatia, provincia de Lampa (PunoPerú). Ecologia Aplicada, 10(1), 41-49.
Peres, C. A. (2001). Synergistic effects of subsistence hunting and habitat fragmentation on Amazonian forest vertebrates. Conservation Biology, 15, 1490-1505.

Poorter, L., \& Bongers, F. (1993). Ecology of tropical forests. Department of Forestry, Agricultural University of Wageningen. Holland.

Prescott-Allen, R., \& Prescott-Allen, C. (1982). What's wildlife worth? Economic contributions of wild plants and animals to developing countries. London: Earthscan.

Robinson, J. G., \& Bennett, E. L. (2000). Hunting for sustainability in tropical forests. In Columbia: Columbia University press.

Robinson, J. G., \& Redford, K. H. (Eds.). (1991). Neotropical wildlife use and conservation. Chicago: University of Chicago Press.

Saha, D., Sundriyal, M., \& Sundriyal, R. C. (2014). Diversity of food composition and nutritive analysis of edible wild plants in a multiethnic tribal land, Northeast India: An important facet for food supply. Indian Journal of Traditional Knowledge, 13(4), 698-705.

Schulp, C. J. E., Thuiller, W., \& Verburg, P. H. (2014). Wild food in Europe: A synthesis of knowledge and data of terrestrial wild food as an ecosystem service. Ecological Economics, 105, 292-305.

Tejada, R., Chao, L., Gómez, H., Painter, R. E., \& Wallace, R. B. (2006). Evaluación sobre el uso de la fauna silvestre en la Tierra Comunitaria de Origen Tacana, Bolivia. Ecología en Bolivia, $41(2), 138-148$.

Termote, C., Meyi, M. B., Djailo, B. D. A., Huybregts, L., Lachat, C., Kolsteren, P., \& Van Damme, P. (2012). A biodiverse rich environment does not contribute to a better diet: A case study from DR Congo. PLoS One, 7(1), e30533.

Termote, C., Raneri, J., Deptford, A., \& Cogill, B. (2014). Assessing the potential of wild foods to reduce the cost of a nutritionally adequate diet: An example from eastern Baringo District, Kenya. Food and Nutrition Bulletin, 35(4), 458-479.

Townsend, W. (1996). Caza y pesca de los Sirionó. Instituto de Ecología, Universidad Mayor de San Andrés. La Paz: FUND-ECO.

Townsend, W., \& Rumiz, D. I. (2003). La importancia de la fauna silvestre para las comunidades indígenas de las tierras bajas de Bolivia. In Biodiversidad: La Riqueza de Bolivia. Estado de Conocimiento y Conservación. Santa Cruz de la Sierra: Fundación Amigos de la Naturaleza.

Van den Eynden, V., Cueva, E., \& Cabrera, O. (2003). Wild foods from southem Ecuador. Economic Botany, 57(4), 576603.

Vega, M. G., Carpinetti, B., Duarte, J., \& Fa, J. E. (2013). Contrasts in livelihoods and protein intake between commercial and subsistence Bushmeat hunters in two villages on Bioko Island, Equatorial Guinea. Conservation Biology, 27(3), 576-587.

Whitmore, T. C. (1983). Secondary succession from seed in tropical rain forest. Forestry Abstracts, 44(12), 767-779.

Wilkie, D. S., \& Carpenter, J. F. (1999). Bushmeat hunting in the Congo Basin: An assessment of impacts and options for mitigation. Biodiversity and Conservation, 8, 927-955.

World Health Organization (WHO). (1992). International Conference on Nutrition: final report of the Conference. Rome: December 1992.

Wright, S. J., \& Muller-Landau, H. C. (2006). The future of tropical forest species. Biotropica, 38, 287-301.

Ziegler, S. (2010). Application of food balance sheets to assess the scale of the bushmeat trade in Central Africa. Traffic Bulletin, 22(3), 105116. 